\title{
Protecting History, Resisting Legibility: Voice and Defiance in Making Art
}

\author{
Alfred Fisher \\ Queen's University, Canada
}

\begin{abstract}
A composer/writer reflects on the struggle to create work of integrity in a captive and commodified culture. Approached from a biographical perspective and from the privileged position of a dual Canadian and American citizen, the author explores the possibilities for the creation of art that arises from historical engagement and process; art that does not conflate the vanities of personal revelation with power of expression or the manipulation of market categories with the steel of intellection. Sources of identity, voice and the faded issue of "authenticity" are examined in the context of legibility and its resistance as American cultural norms.
\end{abstract}

Key words: cultural commentary; self-reflection; historical and cultural literacy.

\section{RESUMEN}

Un compositor/escritor refleja, en la lucha de crear, un trabajo por la integridad en una cultura cautiva y acomodada. Aproximándose desde una perspectiva biográfica y desde la posición privilegiada de ciudadano Canadiense y Americano a la vez, el autor explora las posibilidades de la creación artística que se presenta a través del compromiso y el proceso histórico; arte que no combina la vanidad de la revelación personal con la energía de la expresión o la manipulación de las categorías del mercado con el valor del conocimiento. Las fuentes de la identidad, de la voz y de los asuntos descoloridos de la "autenticidad" se examinan en el contexto de la legibilidad y de su resistencia como normas culturales Americanas.

Descriptores: Comentario cultural; Si mismo-reflexivo; instrucción histórica y cultural.

RÉSUMÉ

Un auteur-compositeur réfléchit sur la lutte pour créer une œuvre d'intégrité dans une culture emprisonnée et réduite au niveau de la production.Abordées d'une prespective biographique et de la position privilégiée de double citoyenneté canadienne-américaine, l'auteur explore les possibilités de créer de l'art qui émerge d'un engagement et d'un processus historiques; un art qui ne gonfle pas les vanités d'une révélation personnelle par la pouvoir d'expression, ou la manipulation des catégories du marché par l'acier du raisonnement. Les sources d'identité, de voix et la question flétrie d' "authenticité» sont examinées, dans le contexte de lisibilité et de sa résistance aux normes culturelles américaines.

Mots-clés: Commentaire sur la culture; reflet de soi; le degré d'alphabétisation historique et culturelle. 


\section{Prelude}

$\mathrm{T}$ He COST OF EQualization of what used to be known unashamedly as "high art" and popular art - the art created for the marketplace - is the collapse of education and the culture of shopping. Just like Tammy-Faye says - "Shopping is cheaper than a psychiatrist." Undeniable though this may be, unlike Tammy-Faye, "high art" may not be a recoverable commodity. The value of its currency plummets while the value of popular art, or, more accurately, pop culture (since distinctions between the two have been rendered superfluous by both its consumers and theorists) soars. In N. America and increasingly in Europe, culture IS pop culture. Everything else is a freak show except for piano competitions, which are so much like professional sports and so perfectly poised for "docudrama," we're prepared to countenance their survival. We're told in as many ways as possible, whether through the media's peculiar penchant for opera arias in luxury car ads or the de rigueur appearance of balding rock bands in orchestra programming, that, to recall the deep insight of John Lennon, we've "come together." The veil that long shrouded our precious conceits has been lifted. With Bono the new Dag Hammarskjold, and Madonna the new Jackie Kennedy, it's better this way.

Not to sound like a deflated old Marxist, but ... People own culture. Nation states sell it. Citizens no longer own their own mythologies. What they own is memory - rapidly vanishing - in places where the past has not already been banished.

We prattle endlessly about diversity, about difference but in reality face mass intolerance for difference that does not have proven market value; this, while difference is valorized in theory and its shadow-client, popular culture. The hottest product in the market place is transgression itself. More than anything else, transgression is the obsession of a society that has not come to grips with just how reactionary it truly is.

\section{History Exiled}

One of the most convenient virtues of the American constitution is that it established a formula for survival by requiring Americans to reimagine themselves every four years in a presidential election. Survival as a polity, of course, does not sum to survival as a culture. Neither Americans nor Canadians will survive ignorance of themselves. With the collapse of historical literacy as knowledge and practice, however, this is precisely the threat facing both societies. "Reality TV" instructs N. Americans in who they are but no amount of "educational programming" effectively inculcates a sense of or an interest in who they were. The demise of historical literacy is the toxic tide that destroys knowledge as a value. Unaddressed, it will destroy the very ability to imagine ideas and, in particular, such antique hegemonic notions as virtue, aesthetic value and an understanding of why knowledge is something that we prize in the first place.

As I formulate it, I have, as a crafter of words and of notes, and as an individual whose inheritance includes a tradition reaching back into the Bronze Age, an important stake in historical literacy and in the "values" that flow from it. 


\section{The Composer and History}

I neither invent nor position myself. I understand my work to arise from a gathering of historically generated ideas and values, filtered through experience, tested in theory, and validated in creative effort. I have no patience, no respect, for what that most despised of American literary critics, Dale Peck, has identified as the "reification of contemporaneity." Indisposed to the worship of false gods - particularly those proselytized in the academic market place, I acknowledge my capture in what is viewed by some as the modernist trap of regretting the absence of a broadly directive, emblematic idea animating either the theoretic or applied side in the arts. Conditioned by memory, regret has become rare and precious. I play at the odd alchemy that would convert a bristling mid-century avant-garde into a sentimentalized ideal - this, the issue of regret and an act of respect. Does its memory not merit protection from the constructed, branded, commoditized "avant-garde," degraded and emptied of power by mass media and the mendacity of a celebrity elite?

The university, once the fortress of the avant-garde, has become a hubristic eunuch complicit in its destruction. As beta and gamma of the global corporate elite, it bravely argues the issue of academic freedom while it cravenly auctions off its independence, exchanging the creation of culture for the creation of products sanctioned by its corporate masters. Neither does it preserve culture as a body of understanding of continuing vitality. But in an increasingly a-historical, a-literate social environment, preservation is warehousing. It is not in the warehouse that profit is generated. The bottom-line "gaze" of the academic industry has no more tolerance for warehousing than does "General Motors."

Within the economies of the mass media, experience is a painstakingly modeled invention, a medium of exchange. But for the artist whose labour and whose reward is not haunted by a seducing, enveloping mass media, experience is never constructed. It is silent. It is innocent. Abstracted in theory, amplified in reflection and mediated by subjectivity, however, experience-become-memory is both fuel and engine - for making art; for understanding a past; for imagining a future. Industrially modeled experience has no future as memory. Industrially modeled memory has no past as experience. Industrially modeled subjectivity has no force. Subjectivity is reduced to brand loyalty. In this, an ethic has been violated; an ethic so foundational that we have no knowledge of our condition and no effective tactical response. Passivity is the measure of defeat. Where experience-become-memory is sustained, however, its potential remains powerful, unique, and unpredictable, converting to energy for creative endeavour and for everything that defines and sustains our humanity - what it is that we hope for, what it is that we see as the limits of art and intellect, hate and love.

The art that interests me is the realization of that potential. It doesn't draw on "blank slates" or industrially generated models and mythologies for creation, practice or comprehension. It draws on cultural literacy and the experience that is both prior and consequent to it. Such mainline liberal-elitist convictions will draw anger and disdain from the pashas of popular culture and their academic harems. It will be recognized as the familiar meta-narrative - the message flashed by the flickering tongue of bourgeois 
condescension and patriarchy. Though held under the forked stick of techno/global/pop industrial might, it refuses to die. Fortunately, this old serpent has no vestigial profitability. It is in the pasha's world, after all, that the creation of profit is art and consumption, value.

The consumer's engagement with market art is largely free of encumbering contingency on historical-cultural-critical competency or on anything beyond the designed vocabularies of mass media. Art framed in experience and made intelligible in the apprehension of ideas and relations is not a tool of elitist arrogance or classist terrorism. For those whose response is contextualized within a still vital, internally protected historical-cultural continuum rather than the non-contextual "in-the-moment" construct privileged in popular culture, the reward of such art, to borrow the language of the marketplace, is the return on that most mysterious but fundamental investment of biology; the brain. The market understands well the risk incurred in ignoring fundamentals. I speak not as a cultural imperialist but from the secure perspective of the not-so-secure culture I refuse to abandon. I speak from within the culture in which my experience is nested. Anything else would be either pretentious, disingenuous or, simply a lie. This is the voice - a still developing voice - that is mine. To speak with this voice is not to "privilege" my experience, nor is it to "privilege" white men and their delusions or Euro-American-Canadian culture in anything but the most trivial sense. I have worked and, not to dramatize, but I have struggled to discover this voice that is mine and it is in this plot that my work is seeded.

Comprehension of pop culture in its performative dimension is normally assumed if only because of its saturating presence. It is, perhaps, because of this that justification lies so close to the surface in much pop culture theory. On the other hand, theory has been intensely focused on comprehension in historical theories of elite culture. Justification is dependent on the polemic and comprehension on the analytic. Theory is validated, however, when it leads to comprehension - not to (or from) justification. A society with no memory, a society afflicted with historical blindness will never comprehend and as comprehension retreats, justification will advance.

\section{"High Art" and Popular Culture}

Associations with wealth, power and entitlement make me uncomfortable with the term "elitist" or "high art." That seems good enough reason to confine myself exclusively to the second term. Unsurprisingly, I hold the first term, the "A Word" to a far more restricted definition than that preferred in pop culture. Pop culture loves art so much that everything from dogshit on the street to pornography on the screen is or can be - pick your theorist - art. It is, perhaps, the stigma of association that makes the idea of "high art" a "high value" target for the burgeoning industry of cultural criticism. Torturing "high art" is the sport of pop culture priests, adult adolescents and, where the vocabulary has penetrated, adolescent adolescents too. There is no entitlement so generally acknowledged or so blithely secure in its exercise as the entitlement to attack the 
notion of "high art." It is a "swarming" of an extravagant, intoxicating bellicosity reserved for no other enemy of civilization.

\section{The Primacy of Communication}

Here is a sadness. The energy that has sustained and replenished the artistic heritage of the West seems depleted. Particularly in new music, indifference or hostility prevails. The monuments survive - largely through the persistence of those who feel defined by them. It is, in the end, our own vanity that forces life back into the slumping body. However reduced, art is resilient. It continues to crouch in the darkness and glow with power. Glow with value. Not a unitary value but a range of values, all linked to what I view as the primary value - communication - and, from the point of view of the artwork itself - communicability - by which I mean both the projected intention of the artist and the inherent power of the artwork itself to communicate.

There will be much agreement on this point from the world of pop culture. While I can argue for the primacy of communication, only pop culture commands the capital resources, the power and the armies of true believers to self-servingly indulge in such "grand synthetic overviews." The response of those deracinated intellectuals on the other side of the divide, pierced by the guilt-poisoned arrows rained down on "cultural imperialists" and their minions, is often specious self-reconstitution and selfhybridization - of their work and even of themselves. Nothing is as creative as the survival instinct itself. My purpose here though, is certainly not to rue the collapse of privilege or, conversely, to denigrate market culture but to draw closer to the front of cultural tensions that makes experience-subjectivity-memory a strength and the core source of creativity.

\section{Accounting to Myself; Subjectivity and Experience}

I recognize that my position is, within the framework of cultural politics, absolutely vulnerable and mostly indefensible; this, because I am not armed as a soldier in the profitless discourse of the so-called culture wars nor, as a non-social scientist, do I scan the rich fields of polysemy in words such as "culture" and "history" with a proper anxiety. I know a little cultural theory; enough to send my own words spinning into a whirlpool of assumption and self-contradiction. It can be really wonderfully stimulating. But after I've revealed myself to myself as an unreconstructed hegemonist who continues to trade in discredited conceits and fantasies, there remains the defining idea, words, and the music which, for me survives all attack save for my own bloody editorial savagery. Even a hegemonist, after all, can deconstruct. And the most fruitful object of deconstruction is oneself. I've learned to deconstruct myself with the intent of maintaining self-legitimacy in a market-saturated environment more likely to arouse selfdoubt than affirmation. But I'm never so sufficiently purified of self-doubt that I'm able to indulge in the postmodern ritual of spontaneous self-valorization. Pity. 
Though not always comforting, the exercise of invigilated self-transparency does offer rewards. For the maker of things on both sides of the cultural divide, the most powerful of these is gaining a perspective on "voice" - which I define as one's expressive identity. For me, the creation of music and the creation of ideas proceed from the same cleft; the same fiery, tender border of experience-subjectivity-memory and social environment that, like the earth's tectonic plates scrape and grind and accumulate power. It is from the fire and hurt of this constant friction that "voice" arises.

But well before the dawning of - please forgive the expression - "tragic awareness," the audaciously free and uncorrupted voice of children reminds us of what was once ours and what we must recover. Even better, what we must protect and never lose. If you, like myself, are still touched by Wordsworth's insight, "the child is the father of the man," then you'll perhaps not reject out of hand what is for me a regularly affirmed sense - that the openness and spontaneity of child mind and child voice as its expression, provides another vision of limitlessness; one without dogma or indeed, faith. It has its terrors, but also its inspirations, visions of the infinitely safe, infinitely fearless, the infinitely and unredoubtedly beautiful. It encourages us to not banish from our adult lives the child's intimacy with the fantastic and the gift to magically exchange a doleful present for imagined past and a future spun of wonder. I'll happily leave it to my colleagues to "reify contemporaneity." My preference is to reify the fantastic. For me, this is a "child mind behaviour" that does indeed map into the life of "maturity" that thin strip of seasons we pass through before we begin to understand anything. As I've passed through them, I've scanned the broad horizon of many years and, to adorn it in Wordsworthian imagery, I have not yet found the patch of grass in which I could not find "splendour."

I have reason to be grateful for this double-sided gift of access of child to adult, of adult to child, of imagined to real, and, yes, of personal to political and return. I'm amused by the late- arriving self-insight that I tend to approach theory as Wordsworth approached flowers: even where the science is understood, it's the poetry that counts. Against all odds, against all sense, I continue to read theory as fantasy and am given to abide comfortingly with the "truth" that is poetry.

The poetry-become-phantasm that is defined as literary theory has in particular encouraged serious, sometimes painful speculation far more regularly than the certitude it seems to inspire in my colleagues in humanities departments. Kristeva and Barthes in particular give me more than pause. Could it be, situated in my academic sinecure as a composer, that I've peremptorily claimed as my own, the romantic/modernist identity of "author" - the "possessive and autonomous genius-father" to use Barthes's words, and, in my self-absorption and pitiful enchantment, not understood that I was no more than an absurd assembler, that I had already been pronounced to be a disincarnated shell - and "dead" to boot?

Notwithstanding my status (you're free to choose here) as either privileged zombie, a monster of presumption in the Barthesian sense or spinner of fantasy in my own inevitably self-serving idealization, I've managed to regularly send out messages - sometimes of the "letter-in-the-bottle" type but, often enough, commissioned work and publications that have generated a certain modest profile in several fields. In all of this, my priority has been authenticity of voice. 


\section{Authenticity}

I've hypothesized "voice" or, at least, "adult voice" as the product of conflict between the inner domain of experience-subjectivity-memory and the outer domain of social environment. For some, such a view is no more than an anachronistic, romantic fable. In current academic discourse, it doesn't compete very well. It's certainly distant from the poststructuralist notion of "voice" characterized by Leitch as "discursive constructions cobbled together from linguistic codes and cultural contradictions imbricated with unconscious libidinal, historical, and sociopathic structures and practices. ${ }^{{ }^{3}}$ From this, I can draw no conclusion other than the surety that I am utterly depraved. Assuming that this is an apt description of character deeply polluted after years of "authorship," am I to understand it to permeate and subsume voice as well? If I cannot rescue my character, can I salvage voice from such corruption? After all, my voice is "me," and, to lapse into the utterly self-serving, this doesn't "sound like me." For the most part, the world of music or, more narrowly, the world of music making doesn't trade in such issues in any way other than by implication. The antithetical universes of the ideational and the performative present a conflict between voice as the self-serving confabulation of the privileged sociopath (author) on the one hand and the conceit of the feckless worker-drone on the other (performer). Both views subvert not only authenticity as legitimate value, but impugn the very integrity of the idea of voice.

It's hard for an individual of my generation not to rise to such bait - even when I dangle it before myself. And no, the fact that many of the theorists themselves are of my generation doesn't cool the indignation, their authenticity being invested in and defended by the "grand synthetic overview" theorists have themselves invented, privileged themselves to possess and weaponize. Forty years ago, "authenticity" was the signature issue of my generation. Though faded as an issue in a world of self-invention, then, to have one's authenticity brought into question was to be jolted to the core. Many of that generation's favoured American writers ... Ginsberg, Kerouac, Baldwin, Salinger and even the skanky young Phillip Roth might aptly be seen is vigilantes of "authenticism." However problematized, the authenticity issue transcends generational ownership. Viewed within a poststructuralist framework, authenticity becomes a fragile proposition fluctuating both in itself and in the way it is interpreted by agents whose mission it is to construct and reconstruct authenticity in support of its interests.

Thus, while authenticity may in fact be more fluid than some would prefer, composers - early poststructuralists all - have never hesitated to override this inconvenience by grasping those sonic cues that most clearly project the sanctioned representation of authenticity - even where it is not attached to voice. As an example, nothing could be more secure in its Canadian authenticity than the call of the loon. For years it has been the "sonic icon" of choice, a kind of "essence in a hoot." Many Canadian composers have invoked the call of the loon in their music. Inspiring as it is to know that my colleagues were privileged to attend summer camp, I'd like to issue a good-natured challenge to any one of these "authenticists", these faux voyageurs to start a fire, set a rabbit snare with a surer hand than this urban American Jew or . . . to search out the place where the bearberry grows so that their delusions might be disarmed and we can talk and smoke in peace. 
Authenticity derived through appeal to some national entity and its symbols, unless it is the moral dimension of voice, unless it is subsumed within ideas of process or structure, is not authenticity at all. While often invented, authenticity is neither acquired, granted or endowed. Authenticity is neither signature nor commodity. Its symbolization easily soils what it was meant to honor. It is a fountain that is quickly exhausted.

\section{"Knowing" and "Not-Knowing." The Imperative of "Legibility"}

Canadian and American culture embrace advanced technology happily. Technology is the secular faith du jour. And, like all the others, it is, of course, the true faith. This same culture has little patience with or respect for abstraction although it lives and dies by formula. Doesn't matter if we're strategizing a seduction, setting international policy or breeding dogs, the first priority is formula. Formula is the respectable tool and the fast track to the realization of a dumbed-down and passive world. But, interestingly, this same technology-intoxicated, formula-fed culture is most uncomfortable with unknowns. It's forgotten how to take pleasure in mystery and is often intolerant of concealment. For it, the unknown has only invert value - that is, its value is established in its elimination or even in its consumption - like a cannibal gerbil mother consuming its own young.

\section{Knowing French Wine and American Presidents}

The imperative of legibility is so abundantly evident in American culture it's difficult to sufficiently distance oneself such that we can begin to understand just how fundamental it truly is. In a wonderfully insightful article in The New Yorker, ${ }^{4}$ Adam Gopnik caught it just perfectly. Exploring the phenomenon of wine writing and evaluation in America and, in particular, the methods and objectives of the influential wine critic Robert Parker, he makes the point that, for Parker, tasting and assessing wine is a serious exercise in consumerism while for the French, it is an exploration of their own grand mystique. One of the glories of French culture is reduced, by Parker, to "commodity." His goal is to provide the consumer with an objective basis for making purchasing decisions by assigning a number to each wine tasted. Having thus resolved what in the American view is pretentious and untrustworthy but to the French is beyond quantification, the American consumer is properly equipped to overcome the bafflement of Gallic subtlety and make an intelligent purchase. The French, of course, deplore this. They see it as an act of cultural desecration. As Gopnik points out, a Gevrey-Chambertin is great because - well, because it is Gevrey-Chambertin - not because some guy from the American suburbs assessed it as a "95."

Intolerance of concealment as a key to understanding American thought, literature and public life is brilliantly developed in Michael Gilmore's, Surface and Depth - work that has powerfully informed my thinking on the topic..$^{5}$ As an example of this habituated American behaviour, not only is it the mission of the media to know about George Bush's religious life, it is Bush's mission to tell you. Knowing this, we axiomatically "know him." Knowing him, we "understand him." For the media to "know" Bill Clinton, how- 
ever, required that we "know" his intimate life - something that, unlike Bush's relationship with God, President Clinton was not enthusiastic about sharing with the public. Conclusion? Religion in the White House is good. Sex in the White House is bad. But that distinction is immaterial to the requirement that both be brought to the light of public scrutiny so that concealment is banished and presidential character become "legible." "Knowing" presidents as we "know" that formerly mystical bottle of Gevrey-Chambertin, we can get on with the business of good government and fine wine.

\section{"Legibility" and Music}

In the academy, the potency of legibility has been made evident in the context of ideological shifts in the conduct of academic work. The "kind, old" scholarly ideal of "disinterested pursuit of truth" is one for which I still have some nostalgia. Its inheritors, however, have banished it as a charade; a scholarly shadow-play serving only entrenched interests. New scholarship has replaced it with an array of more subjective, theoretically driven - which is to say, ideologically driven - visions of truth; truth that has long lain suffering and hidden beneath the shroud of "disinterest."

Musicology, as an example, has advanced a model through which scholars might access new and previously taboo understandings of composers and their music. A brilliant example is to be found in Nadine Hubbs' The Queer Composition of America's Sound: Gay Modernists, American Music and National Identity. ${ }^{6}$ Hubbs' argument expands the conventional wisdom that a small group of American composers active between the 20's and 50's including among others, such luminaries as Aaron Copland and Leonard Bernstein can be understood to have sonically defined an "American sound". But Hubbs is interested in another critical identificational feature in the lives of these composers that is determinative for their music. It is rooted in territory far more fundamental than that of national origin. Her reach extends beyond the conventions of national "sonic iconography" to embrace arguments re. personal, perhaps even biological "sonic identity." For Hubbs, the critical fact is not the attribution of common musical traces to national origin - after all, both composers were Jews but one generation removed from the European stettl - but to a deeper identity; to sexual identity. Thus, Hubbs is able to speculate that the open chordal spacing, dance rhythms, hymn tunes, diatonic harmonies and diatonic dissonance - that had been thought to capture a kind of composite musical signature of America was something else; fundamentally something else. This assumedly American sound was at a deeper level to be understood as the "gay sound." Music is a profound identifier but one's sexual identity is the most profound of identities.

For the purposes of this discussion, though, there are two points relating to the legibility issue that flow from Hubbs' work. The first is that to "know" these composers requires that we "know" what their music "signifies," which is to say that we "know" their subjectivity and experience, in this case leading to and flowing from their sexual identity. We "out" the composers, and in so doing, we make them "legible."

The second point refers back to the unicameral, corporately determined culture that, in the face of diversity and its claims, American culture has become. Within this 
reduced cultural geography, sexuality has been commodified no less than music. Identity itself has become commodity. In Berlant's bold, unblinkered view, "Identity is marketed in national capitalism as a property. It is something you can purchase or purchase a relation to. Or it is something you already own that you can express; my masculinity, my queerness." Foucault too has shown, as cited in Berlant ... how "sexuality is the modern form of self-intelligibility; I am my identity; my identity is fundamentally sexual and my practices reflect that."

Hubbs goes to some length to avoid conflation of identity domains and is clearly innocent of intent to appropriate from any one group what is more justifiably claimed for another; the claim, as per example, that the sonic features of, say, Copland's music from the 20's to the 50's may not be emblematic of national identity or sexual identity at all, but, rather, of "Jewishness," or, to cover all bases, gay "Jewishness." But purity of intent does not obviate underlying conflict. What is in Copland's case circumstantially gay is also happenstantially Jewish. The sonic instantiation of this heterogeneous dyad, and the conversion of each (separately? together?) into idealized, sentimentalized, politicized, "Rockwellized" American virtues of simplicity, goodness, accessibility and innocence is a masterpiece of critical alchemy that manages to rescue both gays and Jews from both historical debasement and the malignancy of popular convention. Forget klezmer. Think hoe down.

God bless America.

\section{Resisting "legibility"}

I'm not a musicologist. Living in the life of the composer, my vision is internally focused. But the work of a composer can also be understood as more concrete, even more "objective" than that of a musicologist. It begins with knowledge of materials and techniques. But, very importantly for me, this objective knowledge is nested in a field of purpose and motivation, in history, ideas and in language without which even the most inventive compositional blacksmithing holds no interest for me. When nothing is said, I cease to listen. When I have nothing to say as a composer, I am unashamedly mute. There is other knowledge. There are other modalities. But pop culture does not know silence. It is a constant signal. Its designed frequencies denote a domain of revelation and revelation is both content and ritual; a ritual in which the consumer is the captive witness to the confession of the all-powerful shaman.

I am not of that culture. Mine is a historical culture. Mine is a minority culture. Why should I uncover my own nakedness before you? While the weight and force of content is matchless, I have no interest in forcing my hermeneutic on you. I don't actually care that much about it myself. Why should you?

I cannot imagine the scholar so odd or the necromancer so bored that she would be moved to decode my message. If it were decoded, would it be my sexual identity or, perhaps, my blood type that provides the key? Or will it be my preference for the $<0,1,4>$ set?' Having thought about it occasionally over the years, I've decided that my music actually does have function. It is to preserve me; and, in particular, to preserve what I wish to remain obscure. It is to protect the content of an interior by trans- 
forming it and sending it forth; by showing it respect in creating the most powerful means for its transformation and projection. In the domain of subjectivity and experience, one confronts the face of enigma and the heart of creative power. It doesn't seem wise to peer directly into a radiance so bright. In acknowledging this, one confronts the irony of contexts in which "not knowing" is not only preferable - but also empowering. Obscurity need not be a source of anxiety. Sometimes, it is an inspiration - even a tool.

Notwithstanding the fundamental cultural shifts that have marked the American course over the past thirty years, the ancient faith in the catharsis of disclosure continues to race through the annals of American experience - from John Winthrop to Eminem. There is, however, a line of thought arising within the American historical context that moves in a different direction. It is thinking that resonates familiarly and still powerfully in the words of Emerson: "It is easy in the world to live after the world's opinion; it is easy in solitude to live after our own; but the great man is he, who in the midst of the crowd keeps with perfect sweetness the independence of solitude." 10

Freedom of conscience, independence of mind, is aligned with authenticity of "voice" - and with the promise of another kind of independence - a truly radical independence; the artist's freedom from the reader/listener's "entitlement to 'know."' Whitman strides forward fiercely to pierce the heart of the philistine, flaunting his reader's presumed entitlement with this short poem from the Leaves of Grass.

\section{To A Certain Civilian}

Did you ask dulcet rhymes from me?

Did you seek the civilian's peaceful and languishing rhymes?

Did you find what I sang erewhile so hard to follow?

Why I was not singing erewhile for you to follow, to understand - nor am I now;

(I have been born of the same as the war was born,

The drum-corps' rattle is ever to me sweet music, I love well the martial dirge,

With slow wail and convulsive throb leading the officer's funeral;)

What to such as you anyhow such a poet as I? therefore leave my works, And go lull yourself with what you can understand, and with piano-tunes,

For I lull nobody, and you will never understand me.

\section{The Mystery of the Loon}

I cite these readings not as another trope on Emerson's image of the heroic status of the misunderstood individual ("To be great is to be misunderstood"). ${ }^{11}$ Misunderstanding, after all, is a post factum. Misunderstanding is the enterprise of the critic both in its creation and correction. Art is not kindled in misunderstanding but in knowledge and desire. Free from presumption and intrusion, art defies the constructed articulations of pop culture and the barriers it imposes for both creator and consumer to an understanding of self as the decisive and responsible receiver/conduit of history. Art destroys delusion and creates wilderness; wilderness that, like nature itself, beckons us to enter, explore, probe; beckons us to renew experience and attach memory. It was the intrepid 
explorer Thoreau, who discovered in the seemingly limitless, that there is a place where vision might continue but exploration must end. A century and more before Canadian composers thought to elevate the loon to the status of totem animal, Thoreau opened a deep vein of wisdom at Walden Pond. He did it by observing loons. ${ }^{12}$ It was the loon that taught him that however carefully one measures and predicts, it is nature and not ourselves that shapes and defines what it is that we can "know." He realized this by observing the loon diving through the sacred waters - waters he described as "God's drop." No matter how diligently he observed, he was never able to accurately predict where the loon would reappear at the surface. Not-knowing has rarely been so rich in its rewards.

The loon can be made emblematic, but it can't be made "legible."

We are left as was Thoreau, staring into an evanescent Walden, fallen into impassive nature and into its message - "you cannot, you need not penetrate my mask."

It is this message that potentializes the impulse to make art.

The mask that we must penetrate is our own.

\section{Notes}

1 Tammy Faye Bakker, now an icon of American pop culture, is the ex-wife of the "fallen" televangelist, Jim Bakker.

2 For more on Peck's critical views, see Daniel Mendlessohn's Nailed!, New York Review of Books, Vol. 15, number 12, July 15, 2004.

3 Vincent B. Leitch, Cultural Criticism. Literary Theory, Poststructuralism, (New York: Columbian University Press, 1992), 155.

4 Gopnik, Adam. “Through a Glass Darkly.” The New Yorker Sept. 6, 2004: 157-162.

5 Michael T. Gilmore, Surface and Dept: the Quest for Legibility in American Culture (New York: Oxford University Press, 2003)

6 Nadine Hubbs, The Queer Composition of America's Sound: Gay Modernists, American Music, and National Identity (Berkeley: University of California Press, 2004)

7 Ibid, p. 17

8 Ibid, p. 17

9 As in mathematics, a set in music is a collection of distinct entities, commonly but not exclusively pitches (pitch classes) that is subject to processing as a whole.

10 Ralph Waldo Emerson, "Self-Reliance" in The Essential Writings of Ralph Waldo Emerson, ed. Brooks Atkinson (New York: The Modern Library, 2000), 136.

11 Emerson, op. cit., p. 138

1211 pgs 